\title{
A DESAPROPRIAÇÃO COMO INSTRUMENTO CONSTITUCIONAL DE COMBATE AO TRABALHO ESCRAVO CONTEMPORÂNEO
}

\author{
EXPROPRIATION AS CONSTITUCIONAL MEAN OF COMBATING CONTEMPORARY \\ SLAVE LABOR
}

Germano André Doederlein Schwartz

Reitor do Centro Universitário Ritter dos Reis (UniRitter), da FADERGS e do IBMR. Doutor em Direito (UNISINOS) com estágio-sanduíche na Universidade de Paris X-Nanterre. Estágio pós-doutoral na University of Reading. Bolsista de Produtividade em Pesquisa CNPq (Nível 2). Pesquisador Gaúcho (FAPERGS).

E-mail: germano.schwartz@laureate.com.br

Mártin Perius Haeberlin

Doutor em Direito (PUCRS) com estágio sanduíche na Universidade de Heidelberg. Estágio pós-doutoral na UFRGS. Pesquisador Visitante do Max-Planck-Institut. Professor da Graduação em Direito e do Mestrado em Direitos Humanos do Centro Universitário Ritter dos Reis (UniRitter).

E-mail: martin_haeberlin@uniritter.edu.br

\section{Gabriela Di Pasqua Pereira}

Mestranda em Direitos Humanos pela UniRitter, com bolsa da CAPES (Processo nº 88882.367100/2019-01). Graduada em Direito pela UniRitter. Assessora Jurídica do Ministério Público do Rio Grande do Sul.

E-mail: gdipasqua@outlook.com

Recebido em: 26/06/2020

Aprovado em: 25/09/2020

RESUMO: O presente artigo busca analisar a desapropriação inserida no artigo 243 da Constituição Federal por meio da Emenda Constitucional $n^{\circ}$ 81/2014 a partir de três problemas: a) como se realiza a desapropriação em razão da exploração da mão de obra escrava?; b) qual a conexão entre a carência de regulamentação legal da desapropriação e o conceito de trabalho escravo?; e c) a aplicabilidade do artigo 243 depende da sua regulamentação legal? Esses problemas são absorvidos pela hipótese central de que o novo dispositivo constitucional é um instrumento eficaz de combate ao trabalho escravo contemporâneo no Brasil. O plano de trabalho, estruturado em torno dessa hipótese e realizado com metodologia exploratória de caráter bibliográfico, é desenvolvido em três partes, cada qual relacionada aos problemas apresentados. Na primeira parte, trata-se da inovação constitucional da desapropriação em razão do trabalho escravo. Na segunda parte, coloca-se em pauta a carência de regulamentação legal da Emenda Constitucional $n^{\circ} 81 / 2014$ e se aborda a discussão sobre o conceito de trabalho análogo ao de escravo previsto no artigo 149 do Código Penal Brasileiro a partir do polêmico Projeto de Lei $n^{\circ}$ 423/2013. Na última parte, analisa-se a questão relacionada à necessidade de regulamentação do referido dispositivo constitucional, concluindo que, embora a regulamentação legal possa se fazer necessária do ponto de vista da melhor técnica constitucional e processual, a posição de norma constitucional protetora de direito fundamental do dispositivo permite gerar efeitos essenciais Revista de Direito Brasileira | Florianópolis, SC | v. 26 | n. 10 | p. 292-310 | Mai./Ago. 2020 
independentemente de regra regulamentadora.

Palavras-chave: Desapropriação. Direitos Humanos. Escravidão Contemporânea. Trabalho Escravo Contemporâneo.

ABSTRACT: The purpose of this article is to analyze the expropriation inserted in article 243 of the Federal Constitution by the Constitutional Amendment 81/2014 from three problems: a) How is expropriation due to slave labor exploitation is carried out? b) What is the connection between the lack of legal regulation of expropriation and the concept of slave labor? and c) Does the applicability of the article 243 depends on its legal regulation? The understanding of these problems is absorbed by the central hypothesis that the new constitutional rule is a effective instrument to combat contemporary slave labor in Brazil. The work plan, structured around this hypothesis and carried out with exploratory methodology of bibliographic research is developed in three parts, each one related respectively to the problems presented. In the first part, it deals with the new constitutional rule of expropriation due to contemporary slave labor. In the second part, the lack of legal regulation of the Constitutional Amendment 81/2014 is examined, and the discussion about the concept of slave-like labor provided in article 149 of the Brazilian Penal Code is addressed from the controversial Bill 423/2013. In the last part, the need for regulation of the constitutional article is analyzed, concluding that, although legal regulation may be necessary from the $\mathrm{p} \neg$ oint of view of the best constitutional and procedural technique, its position as fundamental right protection rule added to the provide essential effects regardless the lack of regulation.

Keywords: Contemporary Slavery. Contemporary Slavery Labor. Expropriation. Human Rights.

SUMÁRIO: Introdução. 1 A hipótese de desapropriação em razão da exploração do trabalho escravo no Brasil. 2 A carência de regulamentação legal da EC No 81/2014 e o problema do conceito. 3 Regulamentar para desapropriar? Considerações finais. Referências.

\section{INTRODUÇÃO}

Foi num domingo, um domingo de 13 de maio de 1888, quando a aurora despertou no ainda imperial Brasil e os gritos de liberdade ecoaram. Havia, finalmente, sido sancionada pela Princesa Isabel a Lei $\mathrm{n}^{\mathrm{o}}$ 3.353, abolindo a escravidão do território brasileiro.

Ocorre que, mesmo após cento e trinta anos da abolição formal da escravatura no Brasil, por meio da conhecida "Lei Áurea", a escravidão ainda é uma realidade no Brasil e no mundo.

As novas formas de escravidão apresentam-se em diferentes versões e nomenclaturas, como, por exemplo, "trabalho escravo contemporâneo", "trabalho análogo ao de escravo", "situação análoga a de escravidão", "neoescravidão" ou "escravidão contemporânea."

Denominada de diferentes formas e visualizada sob diversos aspectos, a realidade que assombra é a persistência da escravidão em pleno século XXI, acompanhada de relatos chocantes das situações indignas a que são submetidas milhares de pessoas, muito similares às versões clássicas do instituto.

Diante do alarmante contexto fático, o Estado Brasileiro veio a reconhecer internacionalmente a existência da escravidão contemporânea em território nacional, assumindo o compromisso de erradicar tal prática, a qual consiste em uma das maiores violações de direitos humanos e fundamentais já existente, vindo a ser tipificada como crime no Código Penal Brasileiro.

Além disso, buscando constitucionalizar um instrumento de combate contra a escravidão contemporânea, em 2014, após vários anos de tramitação legislativa, foi promulgada a Emenda Constitucional $n^{\circ}$ 81/2014, que alterou o artigo 243 da Constituição Federal (CF), incluindo a 
possibilidade de desapropriação das propriedades utilizadas para prática do trabalho escravo, consistindo em verdadeira sanção aos financiadores da escravidão.

Com o advento da Emenda Constitucional $n^{\circ}$ 81/2014, contudo, grandes debates foram travados em torno da falta de regulamentação legal do dispositivo e do conceito de escravidão contemporânea, o que resultou na redação do Projeto de Lei no 432/2013, tendo esses dois objetivos como escopo de regulação.

Diante desse cenário, o presente artigo trabalha três problemas: a) como se dá a hipótese de desapropriação em razão da exploração da mão de obra escrava? b) qual a conexão entre a carência de regulamentação legal da desapropriação e o conceito de trabalho escravo? e c) a aplicabilidade da EC nº 81/2014 depende da sua regulamentação legal?

Do ponto de vista dessas questões, a pesquisa sobre a temática justifica-se, de um lado, pela inovação normativa e, de outro, pelo fato do fenômeno aqui envolvido agredir diretamente direitos humanos e fundamentais, sugerindo-se a discussão daqueles problemas a partir da hipótese central de que o novo dispositivo constitucional é um instrumento válido, eficaz e eficiente de combate ao trabalho escravo contemporâneo no Brasil.

A partir desse panorama, o plano de trabalho estrutura-se em torno da referida hipótese e realizado com metodologia exploratória de caráter bibliográfico, especialmente em pesquisa jurisprudencial e consulta aos órgãos fiscalizadores do trabalho escravo e ONG's, sendo desenvolvido em três partes. Na primeira parte, busca-se visualizar a desapropriação em razão do trabalho escravo contemporâneo, tratando brevemente como tal alteração foi inserida na ordem constitucional, estudando sobre a natureza dessa intervenção estatal na propriedade, e sua relação com o combate à escravidão contemporânea. Na segunda parte, coloca-se em pauta a carência de regulamentação legal da Emenda Constitucional $n^{\circ}$ 81/2014, fazendo uma análise teórica da aplicabilidade das normas constitucionais, e abordando, suscintamente, a discussão sobre o conceito de trabalho análogo ao de escravo, previsto no artigo 149 do Código Penal, pelo viés do polêmico Projeto de Lei $n^{\circ}$ 423/2013. Por fim, busca-se responder a existência da necessidade, ou não, de regulamentação do dispositivo constitucional para fazê-lo surtir efeitos na ordem jurídica.

Dessa forma, o objetivo central do presente trabalho consiste em analisar a Emenda Constitucional $n^{\circ} 81 / 2014$ como um instrumento de combate à escravidão e sua aplicabilidade. Alinhado a esse objetivo, busca-se analisar brevemente os aspectos da tramitação legislativa da EC 81/2014; analisar a desapropriação prevista pela nova redação do artigo 243 da CF; estudar a temática envolvendo a regulamentação da emenda e do conceito de trabalho escravo, analisando suscintamente o PL no 432/2013; e investigar a conexão entre a falta da regulamentação legal do dispositivo constitucional e sua aplicabilidade.

\section{A HIPÓTESE DE DESAPROPRIAÇÃO EM RAZÃO DA EXPLORAÇÃO DO TRABALHO ESCRAVO NO BRASIL}

A Emenda Constitucional no 81, de 5 de junho de 2014 (EC no 81/2014) alterou o artigo 243 da Constituição Federal, para nele incluir como hipótese de desapropriação, além da já prevista modalidade de desapropriação por uso de propriedade para cultivo de plantas psicotrópicas, as terras utilizadas para prática do trabalho escravo.

A tramitação do Projeto de Emenda no 232 de 1995, que deu origem à EC nº 81/2014 (conhecido como "PEC do trabalho escravo"), perdurou por aproximadamente treze anos, tendo sido apontado nacional e internacionalmente como um dos projetos mais importantes da atualidade (TREVISAM, 2015, p. 120). Sua origem ocorreu, portanto, justamente no ano em que o Brasil reconheceu a existência da escravidão contemporânea no território nacional (AUDI, 2006, p. 76), tendo sido esse um dos argumentos de justificativa elencados no documento inicial da proposta de alteração, formulado pela Câmara dos Deputados à época. 
A EC no 81/2014 alterou a redação original do artigo 243 da CF, que passou a vigorar da seguinte forma:

Art. 243. As propriedades rurais e urbanas de qualquer região do País onde forem localizadas culturas ilegais de plantas psicotrópicas ou a exploração de trabalho escravo na forma da lei serão expropriadas e destinadas à reforma agrária e a programas de habitação popular, sem qualquer indenização ao proprietário e sem prejuízo de outras sanções previstas em lei, observado, no que couber, o disposto no art. $5^{\circ}$.

Parágrafo único. Todo e qualquer bem de valor econômico apreendido em decorrência do tráfico ilícito de entorpecentes e drogas afins e da exploração de trabalho escravo será confiscado e reverterá a fundo especial com destinação específica, na forma da lei (BRASIL: Emenda Constitucional $n^{\circ}$ 81/2014).

Como pode ser observado, o texto final da EC $\mathrm{n}^{\circ}$ 81/2014 estendeu a sanção às propriedades urbanas flagradas na prática do trabalho escravo e incluiu a necessidade de regulamentação legal para o processo desapropriatório, não obstante tenha indicado destinação específica aos bens expropriados, relacionando-os à reforma agrária e a programas de habitação popular.

Outra mudança evidente na emenda foi a retirada da hipótese de assentamento aos colonos submetidos à escravidão, bem como a reversão do confisco a fundo especial com destinação própria, a ser regulamentada por legislação específica.

A alteração constitucional efetuada pela $\mathrm{EC}^{\circ}$ 81/2014 trouxe ao ordenamento jurídico, portanto, nova modalidade de desapropriação, prevendo um poder-dever de intervenção do Estado na propriedade particular quando flagradas situações de exploração do trabalho escravo em terras de zonais rurais e urbanas, independentemente de indenização ao proprietário. Por essa razão, o acréscimo chegou a ser considerado uma nova Lei Áurea (BRASIL: Em Discussão, 2011).

$\mathrm{O}$ direito de propriedade, como se sabe, é tutelado constitucionalmente pelo artigo $5^{\circ}$, inciso XXII, da $\mathrm{CF},{ }^{1}$ o que indica a impossibilidade de supressão dessa garantia. É também um direito conectado à liberdade no sentido das relações econômicas diante do Estado, sendo considerado livre, nessa linha, aquele que detém o poder de usufruir e dispor da sua propriedade como desejar (FACHIN, 2006, p. 255).

Contudo, é importante sublinhar que, diferente do que acontecia até a chamada "constitucionalização do direito privado", o direito de propriedade não é mais considerado como uma garantia absoluta, devendo ser sempre pautado pela função social (CARVALHO FILHO, 2017, p. 832). Trata-se também de um mandamento da escala normativa máxima (artigo $5^{\circ}$, inciso XXIII, da CF) aquele segundo o qual "a propriedade atenderá a sua função social." Esse mandamento é secundado por regra do Código Civil Brasileiro (artigo 1.228, § $1^{\mathrm{o} 2}$ ), que limita o exercício do direito a finalidades legitimadas ou legitimáveis. Por essa razão, entende-se que, em caso de não cumprimento dos ditames da função social, o Estado pode intervir na propriedade particular em prol de um interesse público (CARVALHO FILHO, 2017, p. 832).

Essa limitação conecta-se com o instituto do abuso de direito, considerando que, no artigo $1.228, \S 2^{\circ}$ do Código Civil, encontra-se regra segunda a qual "São defesos os atos que não trazem

\footnotetext{
${ }^{1}$ Art. $5^{\circ}$ Todos são iguais perante a lei, sem distinção de qualquer natureza, garantindo-se aos brasileiros e aos estrangeiros residentes no País a inviolabilidade do direito à vida, à liberdade, à igualdade, à segurança e à propriedade, nos termos seguintes [...] XXII - é garantido o direito de propriedade.

${ }^{2}$ Art. 1.228. O proprietário tem a faculdade de usar, gozar e dispor da coisa, e o direito de reavê-la do poder de quem quer que injustamente a possua ou detenha. $\S 1^{\circ} \mathrm{O}$ direito de propriedade deve ser exercido em consonância com as suas finalidades econômicas e sociais e de modo que sejam preservados, de conformidade com o estabelecido em lei especial, a flora, a fauna, as belezas naturais, o equilíbrio ecológico e o patrimônio histórico e artístico, bem como evitada a poluição do ar e das águas.
}

Revista de Direito Brasileira | Florianópolis, SC | v. 26 | n. 10 | p. 292-310 | Mai./Ago. 2020 
ao proprietário qualquer comodidade, ou utilidade, e sejam animados pela intenção de prejudicar outrem." E, no artigo 1.228, $\S 3^{\circ}$ do mesmo diploma, há previsão de privação da propriedade por interesse público, ao assim dispor: "O proprietário pode ser privado da coisa, nos casos de desapropriação, por necessidade ou utilidade pública ou interesse social, bem como no de requisição, em caso de perigo público iminente."

Verifica-se, portanto, a imposição de um exercício consonante à função social da propriedade não apenas por abstenções, mas em comportamentos positivos impostos ao proprietário (obrigações de fazer), o qual deve exercer seu direito de propriedade em benefício de outrem (OLINSKI e COSTA, 2017, pp. 365-381). A propriedade, diante desse contexto, não é um fim em si mesma, recaindo sobre esse direito subjetivo valores que reclamam interesses sociais (FACHIN, 2006, p. 285).

É nessa exigência constitucional de uma função social da propriedade que se encontra o cerne da desapropriação, a qual é um instituto do Direito Administrativo com natureza e limites traçados constitucionalmente.

Do ponto de vista conceitual, pode-se entender a desapropriação como um procedimento administrativo. Nessa linha, o conceito de José dos Santos Carvalho Filho: “[...] o procedimento de direito público pelo qual o Poder Público transfere para si a propriedade de terceiro, por razões de utilidade pública ou de interesse social, normalmente mediante o pagamento de indenização (CARVALHO FILHO, 2017, p. 872).” E também Maria Sylvia Zanella Di Pietro:

A desapropriação é o procedimento administrativo pelo qual o Poder Público ou seus delegados, mediante prévia declaração de necessidade pública, utilidade pública ou interesse social, impõe ao proprietário a perda de um bem, substituindo-o em seu patrimônio por justa indenização (DI PIETRO, 2017, p. 190).

Infere-se que o entendimento dos autores supramencionados vem embasado, outrossim, na doutrina de Hely Lopes Meirelles, na qual tem-se como uma das características da desapropriação, essa noção do instituto como um procedimento administrativo. O autor também considera a desapropriação como uma forma originária de aquisição da propriedade, porquanto não preceder de título anterior (MEIRELLES, 2009, p. 608).

Em termos de conceito propriamente dito, a doutrina de Hely Lopes Meirelles entende que desapropriação ou expropriação, é uma forma de transferência da propriedade do individual ao Poder Público, condicionada ao resguardo de uma indenização, salvo em exceções constitucionais específicas (MEIRELLES, 2009, p. 608). Conclui-se, portanto, que o autor tratou da desapropriação e expropriação como institutos afins.

O texto constitucional brasileiro dispõe sobre a desapropriação rural, consolidando-a no artigo 184 , caput, da $\mathrm{CF}^{3}$, e sobre a desapropriação de terras urbanas, no artigo 182 , $\S 4^{\circ}$, inciso III, da CF. Quanto a este, previu a possibilidade de exigência pelo Poder Público Municipal de aproveitamento da área urbana pelo proprietário, sendo uma das penas previstas a desapropriação do solo não edificado, subutilizado ou não utilizado. ${ }^{4}$

\footnotetext{
${ }^{3}$ Art. 184. Compete à União desapropriar por interesse social, para fins de reforma agrária, o imóvel rural que não esteja cumprindo sua função social, mediante prévia e justa indenização em títulos da dívida agrária, com cláusula de preservação do valor real, resgatáveis no prazo de até vinte anos, a partir do segundo ano de sua emissão, e cuja utilização será definida em lei.

${ }^{4}$ Art. $182[\ldots]$ § $4^{\circ}$ É facultado ao Poder Público municipal [...] III - desapropriação com pagamento mediante títulos da dívida pública de emissão previamente aprovada pelo Senado Federal, com prazo de resgate de até dez anos, em parcelas anuais, iguais e sucessivas, assegurados o valor real da indenização e os juros legais.
}

Revista de Direito Brasileira | Florianópolis, SC | v. 26 | n. 10 | p. 292-310 | Mai./Ago. 2020 
Ainda, o artigo $5^{\circ}$, inciso XXIV, da Constituição Federal, estabelece que a lei regulamentará o procedimento de desapropriação, mediante indenização ao proprietário, excetuando-se os demais casos previstos no próprio texto constitucional. ${ }^{5}$

Dessa maneira, consistem em pressupostos da desapropriação a utilidade pública e o interesse social. A utilidade pública encontra-se presente nos casos em que o bem é desapropriado por conveniência da Administração Pública, compreendendo-se, em seu âmago, a necessidade pública, a qual é incluída no próprio conceito de utilidade, mas sendo mais específica às situações em que verificada uma situação emergencial justificativa da desapropriação; e, por fim, o interesse social, presente nas hipóteses em que a desapropriação se fundamenta, de forma mais forte, na função social da propriedade, como nos casos de reforma agrária (CARVALHO FILHO, 2017, p. 873).

Os pressupostos desapropriatórios distinguem-se, segundo Celso Antônio Bandeira de Mello, em primeiro, pelas hipóteses legais autorizadoras da desapropriação, tendo-se hipóteses específicas para o Poder Público desapropriar por utilidade pública, as quais diferem dos fundamentos que podem ensejar a atuação do poder expropriatório por interesse social. Em segundo, refere-se também haver diferenças quanto aos prazos de caducidade para declaração da utilidade pública ou do interesse social (MELLO, 2009, p. 867).

O cerne da desapropriação, por conseguinte, é a configuração de uma situação fática com o condão de autorizar a preponderância da coletividade sobre o individual, a fim de afastar um dos direitos fundamentais mais básicos que é a propriedade, em prol de um interesse público concretamente verificado (ARAÚJO, 2018, p. 1.193).

É nesse sentido, inclusive, que a desapropriação se diferencia da servidão administrativa, porquanto a segunda apenas restringe a propriedade do particular em detrimento de um interesse coletivo, não retirando-a por completo, como assim faz a desapropriação (HARADA, 2015, p. 64).

Pode-se observar que existem espécies diversas de desapropriação (comuns e sancionatórias), sendo uma das modalidades de desapropriação-sanção a previsão do artigo 243 da $\mathrm{CF}$, alterado pela $\mathrm{EC} \mathrm{n}^{\circ} 81 / 2014$, nosso objeto de estudo.

Nessa hipótese, a desapropriação equiparar-se-ia ao confisco, pois não assegura ao proprietário qualquer direito à indenização, em razão do ilícito cometido (DI PIETRO, 2017, p. 202). Importante referir, aliás, haver autores que identificam essa modalidade desapropriatória apenas como expropriação (SILVA, 2017, p. 220).

Tal modalidade é conceituada por José dos Santos Carvalho Filho como desapropriação confiscatória, por entender o autor que, na prática, essa espécie é um próprio ato de confisco, inclusive, sem prejuízo de outras sanções, por não resguardar ao proprietário qualquer direito à indenização (CARVALHO FILHO, 2017, p. 954).

Ademais, segundo o autor, a desapropriação prevista no artigo 243 da CF possui características distintas das demais:

[...] na desapropriação confiscatória, por sua própria particularidade, não há ensejo para a expedição de decreto declaratório prévio. Por essa razão, a fase administrativa limita-se à formalização das atividades gerais e as de polícia dos órgãos públicos com vistas à preparação da ação de desapropriação (CARVALHO FILHO, 2017, p. 955).

O suporte fático da desapropriação nessa nova disciplina, assim sendo, é a exploração do trabalho escravo, considerando-se, de um lado, a prerrogativa de o Estado intervir na propriedade particular por motivação do interesse público e, de outro, o interesse público relacionado à proteção da dignidade. Com a promulgação da $\mathrm{EC} \mathrm{n}$ n $^{\circ}$ 81/2014, materializa-se esse interesse público nas

\footnotetext{
${ }^{5}$ Art. $5^{\circ}[\ldots]$ XXIV - a lei estabelecerá o procedimento para desapropriação por necessidade ou utilidade pública, ou por interesse social, mediante justa e prévia indenização em dinheiro, ressalvados os casos previstos nesta Constituição.

Revista de Direito Brasileira | Florianópolis, SC | v. 26 | n. 10 | p. 292-310 | Mai./Ago. 2020
} 
situações em que deflagradas a exploração da mão de obra escrava, penalizando o escravizador no seu direito de propriedade, o que gera duas consequências. A primeira - real e imediata -, a proteção da dignidade do escravizado; a segunda - potencial e mediata -, a funcionalização daquela propriedade e, desde um ponto de vista dissuasório, de outras propriedades em que se encontre situação de trabalho escravo.

Assim, tem-se que a desapropriação das terras é um novo instrumento para coibição do trabalho escravo em âmbito constitucional, conforme ensinam Raquel Iracema Olinski e Ana Paula Motta Costa:

$\mathrm{O}$ art. 243 da Constituição Federal trouxe um novo instrumento de forma de combate ao trabalho escravo contemporâneo, ou seja, a expropriação de terras quando da ocorrência deste. Dessa forma, uma vez que a prática de exploração escravagista acarreta a perda da função social da propriedade, tal medida inovatória de expropriação constitui não apenas forma de repressão, mas também de prevenção de atos de exploração do trabalhador (OLINSKI e COSTA, 2017, p. 377-378).

Do mesmo modo, a inserção de um mecanismo de combate à escravidão no próprio texto constitucional concede à matéria uma roupagem diferenciada, uma vez considerada a superioridade das normas constitucionais no ordenamento jurídico (SILVA, 2017, p. 217).

Pode-se afirmar que a medida contida na EC n ${ }^{\circ}$ 81/2014 é severa, mas extremamente necessária em razão da persistência da prática do trabalho escravo no Brasil, constituindo-se em uma forma de punição ao empregador que explora a mão de obra escrava.

Inclusive, o debate sobre desapropriação de terras em razão da exploração da mão de obra escrava já vinha sendo realizado anteriormente à $\mathrm{EC} \mathrm{n}{ }^{\circ}$ 81/2014, embora, via de regras, as discussões tenham se dado, na sua maioria, considerando-a nova hipótese de desapropriação rural, não como modalidade específica (SILVA, 2008, p. 71-95).

É digno de nota, igualmente, que durante a tramitação da EC no 81/2014, foram travados inúmeros debates favoráveis e contrários à desapropriação de terras por exploração do trabalho escravo, sendo um dos argumentos favoráveis, o qual nos parece pertinente, a impossibilidade do escravizador transmitir sua propriedade aos chamados "laranjas" - pessoas que emprestam o seu nome para a realização de atos ilícitos de terceiros -, a fim de se eximir da punição (BRASIL: Senado Federal, 2011).

Outros argumentos merecedores de notoriedade são aqueles envolvendo os aspectos penais, uma vez que, ao menos prima facie, a desapropriação das terras tem forte caráter punitivo ao criminoso (BRASIL: Senado Federal, 2011).

A desapropriação como instrumento ao combate ao trabalho escravo consiste, portanto, num forte instrumento de efetividade ao princípio da dignidade humana, assim como dos próprios direitos humanos e fundamentais, além de estar em conformidade com o objetivo, elencado no artigo $3^{\circ}$ da $\mathrm{CF}^{6}$, de busca por uma sociedade livre.

Entretanto, vale ressaltar que a previsão do artigo 243 da CF tratou apenas da expropriação e da destinação da área expropriada à reforma agrária e programas de habitação popular. Modificou-se, pois, a proposta inicial de assentamento dos colonos escravizados, o que, se de um lado, poderia se dizer uma forma de reinserção social e recuperação da dignidade dessas pessoas, de outro, enfrentou críticas calcadas no argumento de que a previsão de assentamento dos colonos, antes pensada para os casos específicos de tráfico de drogas, mostrou-se ineficaz. Nesse sentido, a afirmação de José dos Santos Carvalho Filho:

\footnotetext{
${ }^{6}$ Art. $3^{\circ}$ Constituem objetivos fundamentais da República Federativa do Brasil: I - construir uma sociedade livre, justa e solidária.
}

Revista de Direito Brasileira | Florianópolis, SC | v. 26 | n. 10 | p. 292-310 | Mai./Ago. 2020 
A alteração incidiu, ainda, sobre a destinação da propriedade desapropriada. A destinação precedente consistia na entrega da área para assentamento de colonos, com o fim de permitir o cultivo de produtos alimentícios e medicamentosos. Diante da modificação processada pela $\mathrm{EC}^{\circ}{ }^{\circ} 81 / 2014$, as propriedades devem ser destinadas à reforma agrária e a programas de habitação popular. Em nosso entender, andou bem o Constituinte. De fato, a medida de assentamento de colonos é fluida e imprecisa e, como é evidente, rende ensejo a desvios de finalidade, além de se ter revelado ineficaz. Já a reforma agrária e os programas de habitação popular espelham finalidades mais objetivas, inclusive amparadas por legislação específica, o que vincula mais diretamente a Administração (CARVALHO FILHO, 2017, p. 954).

Ressalvadas ambas opiniões, a solução adotada é o motivo de muitos compararem, com viés crítico, a EC no 81/2014 à Lei Áurea: se, de um lado, a lei que aboliu formalmente a escravidão no Brasil não tenha previsto, felizmente, indenização aos ex-proprietários de escravos, de outro, infelizmente, ela não buscou a restauração social das vítimas.

De qualquer forma, a medida de desapropriação trazida pela EC no 81/2014 é de suma relevância para erradicação da escravidão contemporânea no Brasil, merecendo destacar todo esforço empreendido para incluir esse instrumento no texto constitucional, que tramitou por anos no Congresso Nacional.

\section{A CARÊNCIA DE REGULAMENTAÇÃO LEGAL DA EC N 81/2014 E O PROBLEMA DO CONCEITO}

Com o advento da $\mathrm{EC} \mathrm{n}^{\circ}$ 81/2014, grandes debates legislativos, jurídicos e acadêmicos foram travados em torno de um dos pontos mais afetos à alteração constitucional: a falta de regulamentação legal da emenda.

Isso porque o novo texto constitucional do artigo 243 da $\mathrm{CF}$ prescreve que a desapropriação ocorrerá na forma da lei, ficando a cargo da legislação infraconstitucional regular o processo desapropriatório.

Além disso, o poder derivado reformador também encarregou a lei de regulamentar a destinação dos bens apreendidos em decorrência do cultivo de plantas psicotrópicas ou exploração do trabalho escravo, os quais devem ser revertidos a fundo especial com destinação específica, a ser regulado pela legislação ordinária.

Trata-se, portanto, de uma norma constitucional de eficácia limitada, dependendo da legislação ordinária para alcançar sua eficácia plena.

Inicialmente, cumpre salientar que muito discute a doutrina sobre a eficácia e aplicabilidade das normas constitucionais, iniciando pela diferenciação feita entre vigência e eficácia, as quais comumente tem sido analisadas em planos distintos (SARLET, 2017, p. 168).

Para fins desse estudo, adotamos a noção de vigência como correlata à existência da norma, constituindo em pressuposto para sua validade e eficácia, uma vez que, para ser eficaz a norma deve ser dotada de vigência, a qual não se confunde com a própria validade (SARLET, 2017, p. 169).

Em relação à discussão sobre o vínculo entre eficácia e aplicabilidade das normas, temática também fortemente debatida pela doutrina, optamos pelo entendimento que reconhece a existência de conexão entre ambas, não havendo possibilidade de se falar em norma eficaz carente de aplicabilidade (SARLET, 2017, p. 171).

No tocante à eficácia social, Luís Roberto Barroso adota o termo efetividade quando se debruça sobre a temática, aludindo tratar-se do desempenho real da norma (BARROSO, 2015, p. 255). 
Sobre a discussão entre eficácia jurídica e eficácia social, analisando os ensinamentos de Eros Roberto Grau, leciona Ingo Wolfgang Sarlet:

[...] há como sustentar a íntima vinculação entre as noções de eficácia jurídica e de eficácia social (efetividade), a primeira constituindo pressuposto da segunda, sem que, por outro lado, se possam desconsiderar as evidentes distinções entre uma e outra. Além disso, independentemente da terminologia adotada, há que retomar aqui a já referida e perspicaz ponderação de Eros Roberto Grau, que apontou para a circunstância de que a decisão pela aplicação do direito constitui, em última análise, uma opção pela sua efetivação, que não se pode confundir como fato de que, uma vez tornado efetivo o direito - isto é, aplicado ao caso concreto -, este venha a ser executado pelos destinatários, atingindo a finalidade prevista na norma (SARLET, 2017, p. 172).

Igualmente, tem-se a eficácia jurídica (ou apenas eficácia) como uma abrangência da noção de aplicabilidade, sendo uma norma eficaz sempre aplicável, mas não obrigatoriamente aplicada, o que significa que mesmo uma norma dotada de eficácia jurídica pode não atingir sua eficácia social (SARLET, 2017, p. 171).

José Afonso da Silva, por sua vez, dividiu as normas constitucionais em três categorias de eficácia distintas: a) normas constitucionais de eficácia plena; b) normas constitucionais de eficácia contida; e c) normas constitucionais de eficácia limitada ou reduzida. Segundo o autor, as normas da terceira categoria, objeto da nossa análise, não produzem, com a simples vigência, todos seus efeitos essenciais, porquanto essa foi a vontade do legislador constituinte, atribuindo tal tarefa à legislação infraconstitucional ou a outro diploma regulamentador. Outrossim, estabelece que as normas de eficácia limitada podem ser subdivididas em normas de princípio institutivo e normas de princípio programático (SILVA, 1999, p. 82).

Para Gilmar Ferreira Mendes e Paulo Gustavo Gonet Branco, esses dispositivos são classificados como normas de eficácia limitada, dependendo seus efeitos de um ato normativo. De acordo com os autores:

O terceiro grupo de normas constitucionais compõe a classe das normas constitucionais de eficácia limitada (ou reduzida). Estas somente produzem os seus efeitos essenciais após um desenvolvimento normativo, a cargo dos poderes constituídos. A sua vocação de ordenação depende, para ser satisfeita nos seus efeitos básicos, da interpolação do legislador infraconstitucional. São normas, pois, incompletas, apresentando baixa densidade normativa (MENDES e BRANCO, 2017, p. 70).

Sem prejuízo, os autores mencionados também consideram a existência das normas de eficácia programática, tendo-as como uma subespécie das normas de eficácia limitada (MENDES e BRANCO, 2017, pp. 70-71).

Feitas essas pontuações, lançamos mão do entendimento de que as normas constitucionais podem, direta e imediatamente, fazer surtir seus efeitos essenciais, pois são sempre dotadas de algum teor de normatividade. Isso é: inexiste norma constitucional desprovida de qualquer eficácia, uma vez que esses dispositivos possuem qualidade de hierarquia superior, sempre irradiando efeitos jurídicos na ordem instaurada (SILVA, 1999, p. 81).

Não obstante, há níveis de densidade normativa diferentes, como explica Ingo Wolfgang Sarlet:

[...] pode falar-se em normas constitucionais de alta densidade normativa, que, dotadas de suficiente normatividade, se encontram aptas, diretamente e sem a intervenção do legislador ordinário, a gerar seus efeitos essenciais 
(independentemente de uma ulterior restringibilidade), bem como em normas constitucionais de baixa densidade normativa (ou, como prefere Meirelles Teixeira, normas de eficácia reduzida), que não possuem normatividade suficiente para - de forma direta e sem uma complementação por parte do legislador infraconstitucional - gerar todos os seus possíveis efeitos, ressaltando-se que, em virtude de uma normatividade mínima (presente em todas as normas constitucionais) sempre apresentam certo grau de eficácia jurídica (SARLET, 2017, p. 185).

No presente estudo, interessa em especial a segunda hipótese, atinente às normas de baixa densidade normativa, caso do artigo 243 da $\mathrm{CF}$, texto que estabeleceu a necessidade de regulamentação pelo legislador infraconstitucional.

Trata-se aqui das normas constitucionais que apenas alcançam a plena eficácia dos seus efeitos pretendidos quando editado um diploma normativo ordinário ou complementar para sua execução (SILVA, 1999, p. 82). Esse é exatamente o ponto-problema relacionado à falta de regulamentação da hipótese de desapropriação trazida pela EC nº 81/2014.

Concomitantemente à promulgação da $\mathrm{EC}$ n $^{\circ}$ 81/2014, como já mencionado, surgiram discussões sobre a necessidade de regulamentação infraconstitucional específica do dispositivo constitucional alterado. Tais debates não se ativeram apenas ao ponto da falta de regulação da emenda, mas fizeram surgir outra grande divergência: a necessidade, ou não, de uma (nova) definição legal de trabalho escravo contemporâneo.

Foi nesse sentido que se originou o Projeto de Lei $n^{\circ} 432 / 2013$, o qual visa a regulamentar o processo desapropriatório em casos de exploração do trabalho escravo, e também definir o conceito de trabalho análogo ao de escravo, alterando o tipo penal previsto no artigo 149 do diploma punitivo. ${ }^{7}$

O Projeto de Lei $n^{\circ} 432 / 2013$ foi proposto no dia 18 de outubro de 2013 pelo Senador Federal Romero Jucá (elencando todo processo administrativo da desapropriação em relação a prática do trabalho escravo contemporâneo e ainda prevendo um fundo especial específico para coibição dos crimes de escravidão e de tráfico de drogas), enquanto o Projeto relacionado à EC $\mathrm{n}^{\circ}$ 81/2014 ainda se encontrava em tramitação no Congresso Nacional.

Em justificativa ao Projeto de Lei $n^{\circ} 432 / 2013$, o referido Senador afirmou a necessidade de um conceito legal de trabalho escravo, a fim de obtenção de uma base jurídica mais clara dos limites de atuação da desapropriação. Alegou, ainda, a existência de uma subjetividade na verificação dos fatos de exploração da mão de obra escrava, como podemos visualizar em trecho do Parecer de justificativa:

No campo dos conceitos, as certezas não são tão claras e há uma carga de subjetividade nas análises dos fatos. O que é sumamente revoltante para alguns pode não o ser para outros, principalmente porque as condições de trabalho em geral não são lá essas maravilhas nos campos distantes, nas minas, nas florestas e nas fábricas de fundo de quintal (BRASIL: Senado Federal. Projeto de Lei do Senado $\mathrm{n}^{\circ} 432$, de 2013).

No texto, também se alude ao fato de que os conceitos de trabalho forçado formulados pela OIT são vagos, afirmando que a Convenção $n^{\circ} 29$ da Organização já se encontraria ultrapassada, por restringir a situação de trabalho forçado à presença da ameaça e a falta de

\footnotetext{
${ }^{7} \mathrm{O}$ artigo 149 do Código Penal define o crime de trabalho análogo ao de escravo: "Reduzir alguém a condição análoga à de escravo, quer submetendo-o a trabalhos forçados ou a jornada exaustiva, quer sujeitando-o a condições degradantes de trabalho, quer restringindo, por qualquer meio, sua locomoção em razão de dívida contraída com o empregador ou preposto: Pena - reclusão, de dois a oito anos, e multa, além da pena correspondente à violência.
}

Revista de Direito Brasileira | Florianópolis, SC | v. 26 | n. 10 | p. 292-310 | Mai./Ago. 2020 
espontaneidade da vítima ${ }^{8}$, bem como que a Convenção $\mathrm{n}^{\circ} 105$ da OIT não poderia ser considerada como uma referência de conceito, por tratar de "condições análogas à escravidão", o que ampliaria excessivamente as situações a ser enquadradas no tipo penal.

Foi esse o motivo pelo qual o Projeto de Lei $n^{\circ}$ 432/2013 tornou-se um dos maiores embates entre os pesquisadores do trabalho escravo, juristas, jornalistas e ativistas.

Muito embora a EC $n^{\circ} 81 / 2014$ tenha sido promulgada, com ela surgiram inúmeras argumentações acerca da insegurança jurídica em torno do conceito de trabalho escravo e da eventual necessidade de sua definição legal.

Para melhor apresentarmos o quadro fático do problema, vale atentar que a proposta inicial do Projeto de Lei no 432/2013 não abrange os conceitos de trabalho em condições degradantes e jornada exaustiva, os quais englobam a conduta tipificada no artigo 149 do Código Penal como trabalho análogo ao de escravo.

Em um dos trechos do parecer de justificativa da proposta de lei em comento, o proponente afirma que a jurisprudência e a doutrina não conseguem definir o que seria o trabalho análogo ao de escravo, aduzindo que cabe aos operadores do Direito encontrar provas e indícios de que o caso concreto se adequa em condições de escravidão (BRASIL: Senado Federal. Projeto de Lei do Senado $n^{\circ}$ 432, de 2013).

Contudo, o argumento é contraditado pelos pesquisadores da escravidão contemporânea, dos quais muitos afirmam não haver problemas práticos na aplicação do artigo 149 do Código Penal. Nesse sentido, Cícero Rufino Pereira:

O argumento que a definição e o conceito de condições degradantes de trabalho e de jornada de trabalho exaustiva, ainda que se entendesse que fossem genéricas (o que não são, conforme referido em outra parte desse trabalho), a Fiscalização Trabalhista, o Ministério Público do Trabalho, a Justiça do Trabalho, e principalmente, a Justiça Federal e o próprio STF, têm trabalhado de forma muito tranquila, justa e adequada com tais conceitos, há quase 11 longos anos, qual seja desde a publicação da Lei 10.803/2003, quando surgiu no mundo jurídico e no cotidiano de toda sociedade brasileira, os citados conceitos. (PEREIRA, 2014, p. 10-11).

Há, ainda, correntes doutrinárias que defendem uma aplicação mais abrangente do conceito previsto no artigo 149 do Código Penal, para garantia da proteção das vítimas e punição dos autores do crime. Em consonância a essa linha de pensamento, Lívia Mendes Moreira Miraglia:

A interpretação do conceito legal de trabalho em condições análogas à de escravo deve ter maior abrangência, a fim de garantir a tutela plena desses trabalhadores e a efetiva punição dos empregados que cometem o ilícito.

Isso porque, o que se percebe é que o empregador utiliza artifícios para escapar da tipificação legal, valendo-se de outras formas de coação que não caracterizam, em princípio, ofensa ao direito de liberdade da pessoa, mas que afrontam claramente a dignidade da pessoa humana (MIRAGLIA, 2015, p. 133).

Segundo preceitua Leonardo Sakamoto, a mudança do conceito da forma inicialmente proposta pelo Projeto de Lei $n^{\circ} 432 / 2013$ tornaria as vítimas da escravidão contemporânea invisíveis ao Poder Público (SAKAMOTO, 2017, p. 193). O autor também afirma que a definição atual de trabalho análogo ao de escravo vem sendo tranquilamente aplicada pela jurisprudência brasileira:

\footnotetext{
${ }^{8}$ Art. 2 - 1. Para os fins da presente convenção, a expressão 'trabalho forçado ou obrigatório' designará todo trabalho ou serviço exigido de um indivíduo sob ameaça de qualquer penalidade e para o qual ele não se ofereceu de espontânea vontade.
}

Revista de Direito Brasileira | Florianópolis, SC | v. 26 | n. 10 | p. 292-310 | Mai./Ago. 2020 
Varas, tribunais e cortes superiores utilizam a atual definição desse artigo. Em decisões da maioria dos ministros do Supremo Tribunal Federal, fica clara a compreensão de que eles entendem o que são esses elementos - tanto que já receberam denúncias de deputados e senadores por esse crime. Diferentes agências das Nações Unidas divulgaram documento conjunto, em 2016, apoitando o conceito brasileiro e sua aplicação (SAKAMOTO, 2017, p. 193).

Por outro lado, Gilmar Ferreira Mendes e Paulo Gustavo Gonet Branco entendem que a legislação infraconstitucional, reguladora do artigo 243 da CF, deve conceituar o trabalho escravo para fins de segurança jurídica:

Ainda não há, todavia, regulamentação da norma referente à expropriação de propriedades rurais e urbanas nas quais seja identificada exploração de trabalho escravo. É certo que a legislação que venha a disciplinar essa modalidade deverá conter definições bastante claras do conceito de trabalho escravo, bem como assegurar o devido processo legal aos proprietários dos imóveis, evitando, assim, insegurança jurídica (MENDES e BRANCO, 2017, p. 356).

Já na visão de apoiadores das ações de combate ao trabalho escravo, o Projeto de Lei $\mathrm{n}^{\circ}$ 432/2013 é um retrocesso social, tanto que a proposta constitui-se em um dos motivos para criação do movimento "Somos Livres", totalmente contrário à aprovação do projeto de lei em discussão. ${ }^{9}$

Para Christiane V. Nogueira e Renan Kalil, a regulamentação do rito desapropriatório significa, a um só tempo, uma facilitação da aplicação do artigo 243 da CF e um retrocesso de todo sistema protetivo de direitos humanos e fundamentais do trabalhador já conquistados (NOGUEIRA e KALIL, Repórter Brasil, 2015).

Fato é que o Projeto de Lei $n^{\circ} 432 / 2013$ acabou por ser transferido de relatoria, transmitindo-se a proposta ao crivo legislativo do Senador Paulo Paim. No dia 16 de fevereiro de 2017, foi divulgado parecer pela Comissão de Constituição, Justiça e Cidadania, a qual analisou cinquenta e cinco emendas propostas pelos senadores federais, vindo a apresentar um projeto de lei substitutivo.

Posteriormente, em 05 de abril de 2017, foi formulado requerimento pelo Senador Romero Jucá solicitando que a proposta fosse apensada ao Projeto de Lei $n^{\circ} 169 / 2009$, o qual dispõe sobre a proibição das entidades brasileiras estabelecerem contratos com empresas que explorem trabalho escravo (BRASIL: Senado Federal. Projeto de Lei $n^{\circ} 169$, de 2009). O requerimento foi aprovado apenas em 15 de março de 2018, sendo que, atualmente, tanto o Projeto de Lei $n^{\circ}$ 432/2013 e a Proposta $n^{\circ}$ 169/2009 encontram-se arquivados (desde a data de 21.12.2018), em razão do encerramento da legislatura, nos termos do artigo 332, $\S 1^{\circ}$, do Regimento Interno do Senado Federal. $^{10}$

Diante do exposto, podemos estampar o problema aqui tratado da seguinte forma: a) o artigo 243 da CF, em seu texto atual, prescreve que a desapropriação em razão do trabalho escravo contemporâneo deve ter seu rito definido legalmente; b) criado o projeto de lei para tal regulamentação do dispositivo constitucional, surgiu uma grande discussão - ao ver do presente trabalho, ainda longe de esgotamento -, acerca do tipo penal que define o crime de trabalho análogo

\footnotetext{
${ }^{9}$ Mais informações sobre o projeto "Somos Livres" podem ser encontradas por meio do seguinte endereço eletrônico: $<$ http://somoslivres.org>. Acesso em: 20 jun. 2019.

${ }^{10}$ Art. 332. Ao final da legislatura serão arquivadas todas as proposições em tramitação no Senado, exceto [...] $\S 1^{\circ}$ Em qualquer das hipóteses dos incisos do caput, será automaticamente arquivada a proposição que se encontre em tramitação há duas legislaturas, salvo se requerida a continuidade de sua tramitação por 1/3 (um terço) dos Senadores, até 60 (sessenta) dias após o início da primeira sessão legislativa da legislatura seguinte ao arquivamento, e aprovado o seu desarquivamento pelo Plenário do Senado.
} 
ao de escravo; e c) diante dessa divergência e da revolta pública ocasionada, o projeto está em tramitação há anos no Congresso Federal (agora obstado por um arquivamento), sem qualquer previsão de resolução do problema.

Ao fim, o questionamento que persegue a linha de pesquisa traçada no presente estudo, principalmente considerando o contexto fático relatado, é se, de fato, existe necessidade de regulamentação do artigo 243 da CF para efetivação da desapropriação em razão do ilícito do trabalho escravo.

\section{REGULAMENTAR PARA DESAPROPRIAR?}

Consoante temos tratado ao longo deste estudo, a inserção da exploração da mão de obra escrava como hipótese ensejadora de desapropriação, nos termos do artigo 243 da CF, por intermédio da $\mathrm{EC} \mathrm{n}^{\circ}$ 81/2014, trouxe várias divergências, a principal delas relacionada à carência de regulamentação legal do rito desapropriatório, necessidade que veio constante no próprio texto do dispositivo alterado. Partindo desse cenário, com o objetivo de visualizar como o Poder Judiciário vem manejando a alteração constitucional em comento, realizou-se pesquisa jurisprudencial. Entretanto, obteve-se o resultado de inexistência de decisões aplicando o dispositivo do artigo 243 da $\mathrm{CF}$ em situações de exploração da mão de obra escrava desde a promulgação da EC no 81/2014 nas instâncias superiores e nos Tribunais Regionais Federais Brasileiros. ${ }^{11}$

Igualmente, efetuou-se pesquisa jurisprudencial junto ao Tribunal Superior do Trabalho e dos Tribunais Regionais do Trabalho, considerando suas vinte e quatro regiões, sendo identificada, também, a inexistência de qualquer decisão aplicando a desapropriação em decorrência do ilícito do trabalho escravo. ${ }^{12}$

Aproveita-se para assinalar que, embora a competência para processamento e julgamento dos casos envolvendo o crime previsto no artigo 149 do Código Penal pertencer à Justiça Federal, ${ }^{13}$ eventuais ações autônomas para discussões de violações de normas trabalhistas, pedidos de indenizações e outras tutelas correlatas são processadas na seara trabalhista.

Realizou-se pesquisa, outrossim, nos principais órgãos responsáveis pela fiscalização do trabalho escravo, assim como ONG's que se debruçam sobre o tema, ao passo que nada consta em seus endereços eletrônicos acerca da aplicação da desapropriação nos casos de escravidão contemporânea. ${ }^{14}$

\footnotetext{
${ }^{11}$ Realizou-se pesquisa jurisprudencial junto ao STF, STJ, e TRF'S das cinco regiões do País. Assinala-se que os termos selecionados para as buscas foram "artigo 243 da CF", "EC 81/2014", "PEC 438/2001", "Lei 8.257/91", "desapropriação trabalho escravo" e "expropriação trabalho escravo". Até o dia 21 de junho de 2019, no âmbito do TRF da $4^{a}$ Região, com a busca pela indexação "expropriação trabalho escravo," constou uma decisão, a qual deixou de aplicar o artigo 243 da CF em um caso de trabalho escravo por ausência de legislação específica.

12 Os termos escolhidos para tal pesquisa jurisprudencial foram "trabalho escravo e "desapropriação." Não foi localizada decisão aplicando o art. 243 da CF, tão somente causas relacionadas a indenizações trabalhistas. Consignase que os acessos da pesquisa se deram entre os dias 22 e 23 de junho de 2019, nos respectivos endereços eletrônicos dos TRT's e TST.

${ }^{13}$ Apesar do STF não ter julgado a temática em sede de repercussão geral, tampouco sumulado a matéria, a Corte já entendeu, inclusive em Plenário, que a competência para julgar e processar as ações penais relativas ao delito em tela são da Justiça Federal, destacando-se os RE 398041/PA, RE 459510/MT e AP 635/GO, sendo que, essa última, resultou na invalidação, desde o oferecimento da denúncia, de uma ação penal de trabalho escravo que havia sido proposta na Justiça Estadual.

${ }^{14}$ Para fins de justificação da inexistência de dados, discriminam-se as instituições pesquisadas: Ministério Público do Trabalho - MPT; Ministério Público Federal - MPF; Grupo de Apoio ao Combate à Escravidão Contemporânea e ao Tráfico de Drogas - GACEC/MPF; Secretaria do Trabalho; Grupo Especial de Fiscalização Móvel - GEFM/Senado Federal; ONG Repórter Brasil; ONG Escravo nem pensar!; Instituto Nacional de Colonização e Reforma Agrária INCRA; Comissão Pastoral da Terra - CPT. Acessos via portais eletrônicos em 22 jun. 2019.
}

Revista de Direito Brasileira | Florianópolis, SC | v. 26 | n. 10 | p. 292-310 | Mai./Ago. 2020 
Das pesquisas efetuadas, é digna de nota uma decisão prolatada pela $8^{a}$ Turma do Tribunal Regional Federal da $4^{\mathrm{a}}$ Região, em sede de apelação criminal tombada sob o $\mathrm{n}^{\mathbf{o}} 5000420$ 07.2016.4.04.7017/PR em cujo acórdão o colegiado revisou a decretação de perdimento do imóvel pelos réus, determinada em primeira instância, fazendo a seguinte observação sobre o artigo 243 da Carta Política:

A expropriação em liça demanda, destarte, a existência de previsão legal, que regulamente a norma constitucional em comento; logo, essa tem sua eficácia limitada. Inexiste, porém, lei que trate de mote - apenas tramita o Projeto de Lei do Senado de n. 432/2013, que ainda pende de aprovação legislativa (BRASIL. TRF4. AC no 5000420-07.2016.4.04.7017/PR).

Destaca-se que o caso em tela possuía peculiaridades, tratando-se a propriedade em discussão de um bem de família. Porém, a fundamentação manejada para não aplicação da desapropriação foi a ausência de previsão legal do dispositivo constitucional e sua eficácia limitada.

Da pesquisa realizada, constata-se a inexistência de dados que comprovem a aplicação dessa nova espécie desapropriatória, à parte do citado caso - o qual, por isolado, não se pode dizer uma jurisprudência no sentido de orientação consolidada. Porém, pode-se perquirir também que o dispositivo constitucional do artigo 243 da CF, no que toca à exploração da mão de obra escrava, não está sendo utilizado em razão de não possuir regulamentação legal.

Daí, extraímos o questionamento que engloba o subtítulo dessa parte da pesquisa: regulamentar para desapropriar? Consoante exposto em nossa hipótese de trabalho, se a coleta de dados junto aos Tribunais não nos permite uma conclusão, a doutrina indica-nos que a resposta à pergunta é negativa. Nesse sentido, mostra-se interessante uma tentativa de resolução tangencial do problema, aventada por pesquisadores do trabalho escravo, sustentada por dois fundamentos.

O primeiro fundamento consiste na defesa de aplicação da Lei $n^{\circ} 8.257 / 91$ de forma análoga aos casos de exploração do trabalho escravo, corroborada pelo fato do diploma legal regulamentar todo processo administrativo referente às situações de tráfico de drogas (OLINSKI e COSTA, 2017, p. 377).

Assim, a analogia sanaria o problema regulamentar da desapropriação em razão da exploração de mão de obra escrava, tanto a hipótese de desapropriação pelo crime de trabalho análogo ao de escravo quanto para o delito de tráfico de drogas se encontram previstas no mesmo dispositivo constitucional, porquanto possuem fundamento idêntico e pertencem a mesma modalidade de intervenção do Estado na propriedade.

Nesse diapasão, fundamenta Cícero Rufino Pereira:

Pode-se entender que, no mundo jurídico é comum o uso da analogia para se preencher lacunas; então, é perfeitamente cabível a utilização da Lei 8.257/1991 (a qual inclusive trata de questões para serem resolvidas com base no Código Processual Civil - CPC, consoante art. 23 da referida lei) e de seu decreto regulamentador (Dec. 577/1992); tal legislação trata da expropriação de terras onde haja a cultura ilegal de plantas psicotrópicas. Tal é possível, inclusive, porque tanto a desapropriação pela exploração do trabalho escravo, quanto à expropriação por cultura ilegal de plantas psicotrópicas estão no mesmo texto legal, qual seja, o art. 243 da CF/1988, com a redação que lhe deu a EC 81/2014. (PEREIRA, 2014, p. 13)

O segundo fundamento para autorização da aplicação análoga da Lei n ${ }^{\circ}$ 8.257/91, reside no princípio da máxima efetividade dos direitos fundamentais, em conformidade com a previsão constitucional do artigo $5^{\circ}, \S 1^{\circ}$, da Constituição Federal. ${ }^{15}$

${ }^{15}$ Art. $5^{\circ}[\ldots] \S 1^{\circ}$ As normas definidoras dos direitos e garantias fundamentais têm aplicação imediata. Revista de Direito Brasileira | Florianópolis, SC | v. 26 | n. 10 | p. 292-310 | Mai./Ago. 2020 
Dessa forma, até que sobrevenha legislação específica objetivando a efetivação da desapropriação de terras em decorrência do ilícito do trabalho escravo, como uma forma de dar máxima efetividade aos direitos fundamentais, seria uma alternativa interessante a aplicação, por analogia, da Lei $n^{\circ} 8.257 / 91$ (OLINSKI e COSTA, 2017, p. 377).

Desse modo, ainda que a regulamentação do artigo 243 da CF fosse pertinente por questões técnicas constitucionais e processuais, entende-se ser possível extrair efeitos jurídicos da norma a partir de sua disciplina constitucional, uma vez que não há o que falar em norma constitucional completamente destituída de eficácia (SILVA, 1999, p. 81), mesmo que essa seja limitada. Essa eficácia deve ser dimensionada ao máximo, ainda, por envolver matéria relativa a direitos humanos e fundamentais.

Nesse sentido, por oportuno, repisando-se o fato de que a alteração constitucional veio a ser promulgada para resguardar direitos humanos, importa assinalar o fato de que tais direitos transcendem esferas puramente legais, sendo possível invocar um direito humano até mesmo quando não adequado reclamá-los por imposições legais propriamente ditas (SEN, 2010, p. 295).

A inserção da exploração da mão de obra escrava como hipótese de desapropriação no texto constitucional foi uma longa batalha, passada e repassada pelas mãos do Congresso Nacional Brasileiro por diversas vezes e alterada por tantas outras. Foram longos debates e esforços empreendidos pelos atores envolvidos para afirmar que a escravidão persiste no território nacional e que era necessário um instrumento constitucional de coibição para reforçar a importância de buscar a extinção dessa prática no País.

Porém, transcorridos cinco anos desde a promulgação da EC n ${ }^{\circ}$ 81/2014, o resultado obtido é o da não aplicação de um dispositivo que nasceu para ser, no mínimo, revolucionário no contexto de combate ao trabalho escravo no Brasil.

A realidade é que, enquanto se debate, há, segundo o The Global Slavery Index 2018 (WALK FREE FOUNDATION, 2018), 369 mil pessoas vivendo em regime de escravidão no Brasil. Nesse contexto, ao discutir sobre a regulamentação legal, parece se perseguir incessantemente uma lei e deixar um dispositivo constitucional dotado de natureza de direito fundamental e criado para instrumentalizar a coibição de uma das práticas que mais viola direitos humanos no mundo empoeirado em uma prateleira.

\section{CONSIDERAÇÕES FINAIS}

A coisificação da pessoa humana, tão antiga quanto a vida, vem sendo praticada por séculos, estando presente desde os primórdios da existência humana, consistindo em verdadeira violência contra os direitos mais essenciais da pessoa, protetores da sua dignidade como ser humano.

Contudo, decorridos mais de cento e trinta anos da abolição formal da escravatura no Brasil, a escravidão ainda persiste em território nacional, assim como no mundo inteiro, de forma ainda mais cruel e mais ardilosa do que suas apresentações anteriores, porquanto a prática ocorre na sutileza da clandestinidade, enquanto considerável parcela da sociedade consente que o trabalho escravo não é mais uma realidade.

O Estado Brasileiro, após inúmeros indícios preexistentes e denúncias relatando casos de submissão de pessoas à escravidão, veio a reconhecer internacionalmente a existência das novas formas de escravidão em seu território no ano de 1995, tornando-se uma das primeiras nações do mundo a adotar tal medida.

Para erradicação dessa prática tão odiosa e cruel, o Estado Brasileiro, desde o reconhecimento da escravidão contemporânea em seu território, vem adotando inúmeras medidas para combatê-la, tendo se tornado referência internacional no combate ao trabalho escravo, apesar de existir um sentimento atual de retrocesso em razão de cortes orçamentários nas ações de fiscalização e projetos de lei restritivos. 
Uma das principais medidas tomadas pelo País no combate da escravidão foi a promulgação da $\mathrm{EC} \mathrm{n}^{\circ}$ 81/2014, sobre a qual nos debruçamos neste estudo. A Emenda, após anos de tramitação no Congresso Nacional, veio a alterar o artigo 243 da CF para nele inserir, como hipótese de desapropriação, as terras utilizadas para prática do trabalho escravo, consistindo em um incisivo instrumento para combate à escravidão contemporânea.

O estudo realizado, ainda longe de esgotar a matéria, permite algumas conclusões, as quais, podem ser apresentadas em forma de síntese nas sete assertivas abaixo:

i) O instituto desapropriatório constante no artigo 243 da CF trata-se de uma modalidade de desapropriação-sanção, sendo também chamado de desapropriação confiscatória ou simplesmente expropriação;

ii) A inserção da exploração da mão de escrava perdurou por anos no Congresso Nacional, sendo promulgada por meio da $\mathrm{EC}^{\circ}{ }^{\circ} 81 / 2014$, a qual ainda pende de regulamentação legal;

iii) O Projeto de Lei $n^{\circ} 423 / 2013$ foi criado com o objetivo inicial de regulamentar o rito desapropriatório da emenda referida. Porém, também buscava restringir o conceito de trabalho escravo, o que fez com que o projeto causasse revolta pública, ao passo que ele foi transferido de relatoria, emendado e agora teve sua tramitação obstada pelo fim da legislatura, na forma do artigo 332, $\S 1^{\circ}$, do Regimento Interno do Senado Federal, sem previsão de reabertura;

iv) Em pesquisas jurisprudenciais e investigativas nos órgãos de fiscalização do trabalho escravo e ONG's afeitas à temática, detectou-se a inexistência de aplicação do artigo 243 da CF no que toca à exploração da mão de obra escrava;

v) Os resultados obtidos, principalmente por pesquisa jurisprudencial, fazem crer que o Poder Judiciário aguarda, para gerar efetividade ao dispositivo (que possui eficácia limitada), sua regulamentação legal, apesar de não depender essencialmente dela;

vi) Para a resolução tangencial do problema, entende-se que a aplicação da Lei $n^{\circ}$ 8.257/91, de forma análoga aos casos de exploração do trabalho escravo, até que sobrevenha a legislação específica, corroborada pelo fato do diploma legal regulamentar todo processo administrativo referente às situações de tráfico de drogas, pode ser uma alternativa, até mesmo por se tratar da mesma modalidade de desapropriação da primeira hipótese;

vii) A regulamentação legal da $\mathrm{EC} n^{\circ} 81 / 2014$, embora se faça pertinente por questões técnicas constitucionais e processuais, não é necessária, diante de sua posição de norma constitucional e mais, de norma com qualidade de direito fundamental e, portanto, com autorização para aplicação imediata, nos termos do artigo $5^{\circ}, \S^{\circ}$ da CF. Em razão disso, o dispositivo, no que toca aos casos de exploração do trabalho escravo, já pode fazer surtir seus efeitos ditos essenciais.

\section{REFERÊNCIAS}

ARAÚJO, Edmir Netto de. Curso de Direito Administrativo. 8.ed. São Paulo: Saraiva Educação, 2018.

AUDI, Patrícia. A escravidão não abolida. In: VELLOSO, Gabriel; FAVA, Marcos Neves (Coord.). Trabalho Escravo Contemporâneo: o desafio de superar a negação. 1.ed. São Paulo: LTR, 2006. 
BARROSO, Luís Roberto. Curso de Direito Constitucional Contemporâneo: os conceitos fundamentais e a construção do novo modelo. 5.ed. São Paulo: Saraiva, 2015.

BRASIL. Constituição Federal (1988). Constituição da República Federativa do Brasil. Disponível em: <http://www.planalto.gov.br/ccivil_03/constituicao/constituicaocompilado.htm>. Acesso em: 20 jun. 2019.

BRASIL. Senado Federal. Argumentos a favor e contra a PEC 438/01. Disponível em: <https://www.senado.gov.br/noticias/Jornal/emdiscussao/trabalho-escravo/pec-438/argumentosa-favor-e-contra-a-pec-43801.aspx >. Acesso em: 20 jun. 2019.

BRASIL. Decreto-Lei n ${ }^{a}$ 2.848, de 7 de dezembro de 1940. Código Penal. Disponível em: <http://www.planalto.gov.br/ccivil_03/decreto-lei/del2848compilado.htm>. Acesso em 20 jun. 2019.

BRASIL. Senado Federal. Direitos Humanos: a escravidão que precisa ser abolida. Em Discussão: revista de audiências públicas do Senado Federal. Brasília, ano 2, n.7, mai. 2011, pp.7-78. Disponível em:

<http://www2.senado.leg.br/bdsf/bitstream/handle/id/201034/emdiscuss\%C3\%A3o_n7.pdf?sequ ence $=4>$. Acesso em: 20 jun. 2019.

BRASIL. Emenda Constitucional no 81, de 5 de junho de 2014. Disponível em: <http://www.planalto.gov.br/ccivil_03/constituicao/Emendas/Emc/emc81.htm>. Acesso em: 20 jun. 2019.

BRASIL. Lei no 10.406, de 10 de janeiro de 2002. Código Civil. Disponível em: <http://www.planalto.gov.br/ccivil_03/leis/2002/110406.htm>. Acesso em: 20 jun. 2019.

BRASIL. Câmara dos Deputados. Projeto de Emenda à Constituição no 232, de 1995. Disponível em: 〈http://imagem.camara.gov.br/Imagem/d/pdf/DCD27OUT1995.pdf\#page=41>. Acesso em: 08 set. 2019.

BRASIL. Câmara dos Deputados. Projeto de Lei da Câmara nº 169, de 2009. Disponível em: <https://www25.senado.leg.br/web/atividade/materias/-/materia/93110>. Acesso em: 23 jun. 2019.

BRASIL. Senado Federal. Projeto de Lei do Senado nº 432, de 2013. Disponível em: <https://legis.senado.leg.br/sdleg-getter/documento?dm=3773638\&disposition=inline>. Acesso em: 20 jun. 2019.

BRASIL. Câmara dos Deputados. Projeto de Lei no 5016/2005. Disponível em: <https://www.camara.leg.br/proposicoesWeb/fichadetramitacao?idProposicao=280726 $>$. Acesso em 23 jun. 2019.

BRASIL. Senado Federal. Regulamento Interno do Senado Federal. Disponível em: <https://www25.senado.leg.br/documents/12427/45868/RISF+2018+Volume+1.pdf/cd5769c846c5-4c8a-9af7-99be436b89c4>. Acesso em 23 jun. 2019.

BRASIL. Tribunal Regional Federal da $4^{\mathrm{a}}$ Região. Apelação criminal no 5000420 07.2016.4.04.7017/PR. Apelante: Adenir Stefenon. Apelado: Ministério Público Federal. 
Interessado: Everton Stefenon. Disponível em:

$<$ https://eproc.trf4.jus.br/eproc2trf4/controlador.php?acao=acessar_documento_publico\&doc $=41$ $540390386108592011803416547 \&$ evento $=490 \& \mathrm{key}=5 \mathrm{e} 6 \mathrm{a} 1616 \mathrm{a} 7 \mathrm{~b} 080804 \mathrm{~d} 2 \mathrm{da} 2 \mathrm{f} 830 \mathrm{effcf} 4 \mathrm{a} 900$ 3225f467c63198fdf4d39d0f7852\&hash=de95b9db28c0f01977e3a73249945ab1>. Acesso em 23 jun. 2019.

CARVALHO FILHO, José dos Santos. Manual de Direito Administrativo. 31.ed. rev. amp. São Paulo: Atlas, 2017.

DI PIETRO, Maria Sylvia Zanella. Direito Administrativo. 30.ed. rev. atual. amp. Rio de Janeiro: Forense, 2017.

FACHIN, Luiz Edson. Estatuto Jurídico do Patrimônio Mínimo. 2.ed. atual. Rio de Janeiro: Renovar, 2006.

HARADA, Kiyoshi. Desapropriação: doutrina e prática. 11.ed. São Paulo: Atlas, 2015.

MEIRELLES, Hely Lopes. Direito Administrativo Brasileiro. Atualizada por Eurico de Andrade Azevedo, Délcio Balestero Aleixo e José Emmanuel Burle Filho. 35.ed. São Paulo: Malheiros Editores, 2010.

MELLO, Celso Antônio Bandeira de. Curso de Direito Administrativo. 26.ed. São Paulo: Malheiros Editores, 2009.

MENDES, Gilmar Ferreira; BRANCO, Paulo Gustavo Gonet. Curso de Direito Constitucional. 12.ed. rev. atual. São Paulo: Saraiva, 2017.

MIRAGLIA, Lívia Mendes Moreira. Trabalho Escravo Contemporâneo: conceituação à luz do princípio da dignidade humana. 2.ed. São Paulo: LTR, 2015.

NOGUEIRA, Cristiane V.; KALIL, Renan. Trabalho escravo: risco de retrocesso. 28 jan. 2015. ONG Repórter Brasil. Disponível em: <http://reporterbrasil.org.br/2015/01/trabalho-escravorisco-de-retrocesso/>. Acesso em: 20 jun. 2019.

OLINSKI, Raquel Iracema; COSTA, Ana Paula Motta. Trabalho Escravo Contemporâneo e a Expropriação de Terras à Luz da Função Social da Propriedade como Meio de Combate. In: CONGRESSO NACIONAL DO CONPEDI, 26., 2017, São Luís: Universidade Federal do Maranhão, 2017. pp.365-381. Anais do XXVI CONPEDI, 2017.

ORGANIZAÇÃO INTERNACIONAL DO TRABALHO. Convenção 29, 10 jun. 1930. Disponível em: <http://www.ilo.org/brasilia/convencoes/WCMS_235021/lang--pt/index.htm>. Acesso em: 20 jun. 2019.

PEREIRA, Cícero Rufino. O "Velho" Trabalho Escravo e as Perspectivas do Tema a partir da EC 81/2014. Revista dos Tribunais. Revista de Direito do Trabalho. v.159/2014. pp. 1-15 set. 2014.

TREVISAM, Elisaide. Trabalho Escravo no Brasil Contemporâneo: entre as pressas da clandestinidade e as garras da exclusão. Curitiba: Juruá, 2015. 
SAKAMOTO, Leonardo. Por que o Brasil está desistindo de combater o trabalho escravo? In: PAIXÃO, Cristiano; CAVALCANTI, Tiago Muniz. Combate ao Trabalho Escravo: conquistas, estratégias e desafios. São Paulo: LTR, 2017.

SARLET, Ingo Wolfgang; MARINONI, Luiz Guilherme; MITIDIERO, Daniel. Curso de Direito Constitucional. 6.ed. rev. atual. São Paulo: Saraiva, 2017.

SEN, Amartya. Desenvolvimento como Liberdade. Trad. Laura Teixeira Motta. Rev.Téc. Ricardo Dominelli Mendes. 7.reimp. São Paulo: Companhia das Letras, 2010.

SILVA, José Afonso da. Aplicabilidade das Normas Constitucionais. 3.ed. rev. amp. atual. São Paulo: Malheiros Editores, 1999.

SILVA, Marcello Ribeiro. O Trabalho Escravo Contemporâneo Rural no Contexto da Função Social. Revista dos Tribunais. Revista de Direito do Trabalho. v.132/2008. pp.71-95. Out-dez. 2008.

SILVA, Robson Heleno da. A Expropriação de Imóveis Rurais e Urbanos por Exploração de Trabalho Escravo. In: BRASIL. Ministério Público Federal. Câmara de Coordenação e Revisão Criminal, 2. BARBOZA, Márcia Noll (Coord.). Escravidão Contemporânea. Coletânea de artigos. v.1. Brasília: MPF, 2017, pp. 212-223.

SOMOS LIVRES. Disponível em: <http://somoslivres.org>. Acesso em: 20 jun. 2019.

WALK FREE FOUNDATION, The Global Slavery Index 2018. Disponível em:

<https://www.globalslaveryindex.org/2018/data/country-data/brazil/>. Acesso em 23 jun. 2019. 